\title{
The Effect of Noise on Cortical Auditory Evoked Potential in Cochlear Implant Users
}

\author{
Jihyun Lee, Ji-Hye Han \\ Laboratory of Brain \& Cognitive Sciences for Convergence Medicine, Hallym University College of Medicine, Anyang, Korea \\ 인공와우 사용자들의 대뇌피질 청성 유발전위에 대한 소음의 영향 \\ 이 지 현·한 지 혜 \\ 뇌인지융합의학연구소, 한림대학교 성심병원
}

\begin{abstract}
Purpose: Cochlear implant (CI) users typically complain of impaired ability to understand speech in noise. Previous studies indicate that the detrimental effects of noise can be measured by the change of neural activities. The current study examined the noise effect on psychoacoustic measures while at the same time used cortical evoked potentials to quantify the change of neural processing of speech sounds caused by noise. Methods: Ten adult $\mathrm{Cl}$ users and fourteen normal-hearing subjects were participated in this study. Cortical auditory evoked potentials (CAEPs) were recorded from 64 scalp electrodes in both quiet and noise conditions each during passive and active listening. Speech stimuli were synthesized consonant-vowels with $0 \mathrm{~ms}$ and 50 ms voice onset time (VOT). N1/P2 amplitudes and latencies were analyzed as a function of VOT and listening condition. Behavioral measures as well as a variety of speech perception tasks were conducted. Results: For good $\mathrm{Cl}$ users, speech perception scores in noise condition significantly decreased compared to those in quiet condition for most speech perception tasks. N1 and P2 latencies became prolonged with noise masking compared to the quiet condition. However, unlike what we expected, attentional modulation of CAEPs was not revealed in noise listening. The P2 latency measures were correlated with vowel and consonant perception in noise. Conclusion: The effects of noise masking on temporal processing can be reflected in cortical responses in $\mathrm{Cl}$ users. These results suggest that N1/P2 measures to VOT stimuli with noise masking may represent the change of neural activities in challenging listening situations.
\end{abstract}

Key Words: Cochlear implants, Speech perception in noise, Cortical auditory evoked potentials, Voice onset time.

Received: November 27, 2018 / Revised: January 4, 2019 / Accepted: January 6, 2019

Correspondence: Ji-Hye Han, Laboratory of Brain \& Cognitive Sciences for Convergence Medicine, Hallym University College of Medicine, 291 Simin-daero, Dongan-gu, Anyang 14054, Korea

Tel: +82-31-380-9411 / Fax: +82-31-386-3860 / E-mail: slphan12@gmail.com

\section{INTRODUCTION}

인공와우는 고심도 난청이 있는 사람들의 청신경에 전기적 자극을 직접 제공하는 장치로서 감각신경성 난청으로 상실된 청감각을 보상해줄 수 있다. 언어 습득 이후에 청각 손실을 겪 는 사람들이 인공와우를 사용하기 시작하면, 단기간 내에 말소 리 인식이 크게 개선된다(Ponton et al., 1996; Rouger et al., 2007). 하지만 이러한 말소리 인식 개선의 정도는 듣기 상황에 따라 매우 다르게 나타난다. 일반적으로, 조용한 상황에서는

(c) This is an Open Access article distributed under the terms of the Creative Commons Attribution Non-Commercial License (https://creativecommons.org/licenses/by-nc/4.0) which permits unrestricted non-commercial use, distribution, and reproduction in any medium, provided the original work is properly cited.
인공와우 사용자들의 말소리 인식 능력이 좋으나, 소음 환경에 서는 여전히 말소리 이해에 어려움을 보인다. 뿐만 아니라, 중추 청각 시스템을 포함하는 중추청각 처리 패턴에도 영향을 미치 는 것으로 알려져 있다. 아동의 경우 소음하 듣기 과제를 일정 기간 이상 지속하면 중추청각 처리 과정에 영향을 주게 되어 정 상적인 언어 발달에 나쁜 영향을 미칠 수 있다고 알려져 있다 (Niemitalo-Haapola et al., 2015). 하지만 최근 연구들은 소리 에 주의집중을 기울이는 것이 소음 환경에서의 말지각의 어려 움을 완화시킬 수 있다고 보고하였다(Huyck \& Johnsrude, 2012; Rao et al., 2010). 이는 말소리가 소음에 비해 너무 약해 서 인지할 수 없는 상황에서도 말소리에 집중을 하면 어떤 정보 를 억제하거나 처리하도록 허용해야 하는지를 결정하는 선택적 
인 청각 정보 처리 능력이 향상되기 때문이다(Roelfsema et al., 2010). 그러므로 소리에 대한 집중은 인공와우를 효과적으로 사용하기 위한 학습에 매우 중요한 요소라고 할 수 있다.

우리가 매일 접하는 듣기 환경은 어느 정도의 소음을 포함한 다. 이러한 배경 소음(background noise)은 특히 아동과 청력 손실이 있는 사람들의 언어 이해력을 저하시킬 수 있다. 인공와 우 사용자의 말지각력은 배경 소음에 더욱 크게 영향을 받기 때문에 인공와우 사용자의 소음하 언어 이해력은 그들 내에서 도 편차가 상당히 크다(Fu \& Nogaki, 2005). 이는 제한적인 인 공와우 기기의 주파수 및 시간 정보 처리 능력이 소음 환경에 서의 말소리 변별을 더욱 어렵게 만들기 때문이다( $\mathrm{Fu} \&$ Nogaki, 2005; Hopkins \& Moore, 2009; Won et al., 2007). 선행 연구들은 인공와우 사용자 간의 말지각력 편차를 예측하 기 위해 주관적 검사 방법을 이용하여 검사 결과와 말지각력과 의 상관관계를 조사하였는데, 연구 결과 인공와우 사용자의 청 력 역치(behavioral hearing threshold)는 소음하 말지각 능력 과 상관관계가 낮은 것으로 나타났다(Anderson et al., 2013). 또한 소음하 말지각 능력은 말초 청각 시스템보다 중추청각 처 리 과정과 더 연관성이 높다는 문헌 보고가 늘어나고 있는 추 세이다(Bidelman \& Howell, 2016). 이러한 가설을 증명하기 위 하여 선행 연구들은 중추청각 처리 능력을 효과적으로 평가할 수 있는 대뇌피질 유발전위(cortical auditory evoked potential) 를 사용하여 소음하 듣기와 대뇌 활동성의 관계를 연구하였다 (Anderson et al., 2013; Bidelman \& Howell, 2016). 그러나 정상 청력군을 대상으로 한 대뇌피질 청성 유발전위 연구들은 중추 청각 처리에서의 소음의 영향에 대해 서로 상반된 결과를 보고 하고 있다(Paredes-Gallardo et al., 2018). 일부 연구에서는 말 소리에 의해 N1과 P2가 유발되었을 때, 두 성분의 진폭이 소음 에 의해 감소되었다는 보고가 있는 반면(Dimitrijevic et al., 2013; Zhang et al., 2014), 또 다른 연구에서는 배경 소음으로 인해 N1과 P2의 진폭이 오히려 증가되었다고 보고하였다(Parbery-Clark et al., 2011; Rao et al., 2010).

배경 소음이 인공와우 사용자의 말지각에 상당한 영향을 미 치기 때문에 배경 소음하에서 청각적 변별을 하는 과제에 중점 을 둔 치료 프로그램은 청능 훈련의 효과를 향상시킬 수 있다. 실제로 인공와우 이식 수술을 받은 성인들에게 소음하 말지각 에 중점을 둔 청능 훈련을 실시하였을 때 대부분의 사용자에 서 언어와 음악 인지 능력이 향상된 것이 확인되었다 $(\mathrm{Fu} \&$ Galvin, 2008). 또한 언어 습득 후 청력 손실을 가진 성인 인공 와우 사용자들을 대상으로 소음 환경에서 청능 훈련을 실시한 이후 소음하 말지각 능력이 크게 향상되었고, 훈련 효과는 더 욱 듣기 어려운 조건으로 일반화되었다(Oba et al., 2011). 하지 만 이러한 인공와우 사용자의 수행력 향상을 객관적으로 설명
할 수 있는 대뇌 활동성에 대한 이해와 연구는 아직 매우 부족 한 실정이다. 따라서 본 연구에서는 인공와우 사용과 청능 훈 련으로 인한 말지각 능력 향상의 객관적인 증거를 제시하고, 소 음이 미치는 말지각 능력의 변화 기저에 대한 설명을 제공하기 위해, 인공와우 사용자들의 뇌 활동성이 소음에 의해 어떻게 변화하는지 살펴보았다. 특히, 성인 인공와우 사용자들의 대뇌 피질 청성 유발전위에 대한 소음의 효과를 알아보기 위해 음성 개시 시간(voice onset time, VOT) 구별 과제를 소음 환경에서 수행하였다. 또한, 주의집중에 의한 하향식 처리 방식(top-down processing)이 소음하 말지각력에 어떤 영향을 주는지 알아보 기 위해, $/ \mathrm{ba} /-/ \mathrm{pa} /$ 변별 과제 시 주의집중을 하여 선택하는 능 동 청취(active)와 집중을 하지 않는 수동 청취(passive) 상황에 서 대뇌피질 청성 유발전위를 측정하였고, 각 청취 상황을 소음 이 있는 조건과 없는 조건에서 비교하였다. 이와 더불어, 본 연구 팀의 이전 연구에서 인공와우 사용자의 N1/P2 쌍극자 신호원 활 동성(dipole source activity)과 행동적 말지각 능력이 높은 연관 성을 보였으므로(Han et al., 2016), 본 연구에서는 소음 환경에 서 측정한 인공와우 사용자들의 대뇌피질의 활동성과 소음하 말지각 점수와의 상관관계를 조사하였다.

\section{MATERIALS AND METHODS}

\section{연구 대상}

10 명의 인공와우 사용자(남 4명)들은 신시내티 아동 병원의 임상시험윤리위원회 프로토콜에 따라 모집되었으며, 연령범위 는 32 74세(평균 49.6세)였다. 모든 인공와우를 사용하는 피험 자들은 오른손잡이였으며, 영어를 모국어로 사용하였다. 인공와 우 사용자들은, 인공와우 이식 후 1년이 지났으며, 하루에 적어 도 8 시간 인공와우를 꾸준히 착용하였다고 보고하였다. 10명의 인공와우 사용자 중, 2 명의 난청 발생 시기는 언어 습득 이전, 8 명은 언어 습득 이후이며, 수술 전 청력은 대상자 모두 고도 난 청 이상이었다. 나이, 난청 발생 시 언어 습득 여부, 인공와우 이 식 측(좌/우) 등, 연구 대상자 간의 이질성이 있으나 인공와우 사용자의 모집이 어려워 이들의 데이터 사용이 불가피하였다. 따라서 정상 대조군과의 비교를 통하여 이질성에 의한 약점 보완에 유의하였다. 소음하 말지각력 과제(예: 모음과 자음 식 별, 단어 인지)의 평균 점수를 기본으로 한 복합 점수는 이봉분 포(bimodal distribution)를 이루었다. 이를 바탕으로 10명 중 전 체 말지각력 검사 점수의 50\% 이상인 피험자 6명을 우수(good) 군, $50 \%$ 이하인 피험자 4 명을 저조(poor)군의 두 그룹으로 구별 하였다.

정상 청력군은 14명(남 5명)으로, 연령범위는 22 66세(평균 45.6세)였다. 또한 모두 오른손잡이였으며, 양이 순음청력검사 
결과 $250 \mathrm{~Hz}$ 부터 $8,000 \mathrm{~Hz}$ 까지 옥타브 단위 주파수에서 $20 \mathrm{~dB}$ $\mathrm{HL}$ 이하의 정상 청력을 보였다. 모든 참여자는 동의서 서명 후 실험에 참가하였으며, 참여에 대한 보상을 지급하였다.

\section{자극음}

자극음은 하스킨스 연구소(Haskins Laboratories)가 개발한 Abramson/Lisker VOT 자극음에서 수정한 것으로, VOT가 $0 \mathrm{~ms}$ 인 / ba/ 그리고 $50 \mathrm{~ms}$ 인 $/ \mathrm{pa}$, 두 가지를 사용하였다(http:// www.haskins.yale.edu/featured/demo-liskabram/index.html). 입술에 의한 파열 구간을 지나 모음 /a/로 끝나는 형식으로 구 성되었으며, 자극음의 총 지속 시간은 $180 \mathrm{~ms}$ 로 모두 동일하게 유지하였다. 처음 세 개의 포먼트(formant)의 주파수는 769, 1,232 , 그리고 $2,524 \mathrm{~Hz}$ 였다. 자극음이 시작되는 $50 \mathrm{~ms}$ 구간 동 안 처음 세 포먼트는 모음의 안정기로 증가했다. 올바른 자극 음은 제 1 포먼트에서 최대 진폭으로 상승하고 비주기에서 주기 적인 신호원으로 전환되는 지연 시간이 $10 \mathrm{~ms}$ 였다. 소음 조건 의 경우, 신호대 잡음 비율(singal to noise ratio)이 $+5 \mathrm{~dB}$ 인 음 성 형태의 소음을 음성 자극에 추가하였다. 자극음은 직접 제 작한 Matlab 코딩(MathWorks, Natick, MA, USA)을 이용하 여 Tucker-Davis Technologies (TDT, Alachua, FL, USA)의 $\mathrm{RP} 2.1$ 을 통해 호환 가능한 디지털 사운드 파일로 변환하여 전
달되었고, 동시에 TDT를 통해 신호가 전달되는 시간을 실시간 으로 컴퓨터에 저장하였다. 자극음의 제시 강도는 2260 Investigator (Brüel and Kjær, Nærum, Denmark) 소음계를 이용하 여 보정하였다.

\section{연구 절차}

과제를 수행하는 모든 피험자들은 능동 청취 조건과 수동 청 취 조건을 분리하여 참여하였다. 수동 청취 조건에서는, 피험자 들이 자신이 선택한 영화를 음소거된 상황에서 시청하였으며, 이해를 위해 자막을 제시하였다. 집중에 의한 하향식 처리의 영 향을 최소화할 수 있도록 실험을 시작하기에 앞서 피험자에게 최대한 영화에 집중하고, 자극음은 무시하도록 지시하였다. 능 동 청취 조건에서는, 피험자들이 제시받은 자극음 $(/ \mathrm{ba} / \mathrm{vs} . / \mathrm{pa} /)$ 을 듣고 버튼을 눌러 자극음에 대한 반응을 하도록 하였다. 두 가지 과제 모두 소음 조건에서 실행되었고, 수동 청취 조건은 항 상 능동 청취 조건을 수행한 후에 진행되었다. 전체적인 과제의 흐름과 내용은 Figure 1에 나타나 있다.

피험자들은 과제에 익숙해진 후에, 능동 청취 조건의 과제를 시 작하였다. 정상 청력군은 각 $\mathrm{VOT}$ 자극음당 총 200 회 $(2 \mathrm{VOT} \times$ 200 trials)를 수행하였고, 수행력을 높이기 위해 능동 청취 조건 을 2 블록, 그리고 수동 청취 조건은 1 블록으로 나누어 시행되었
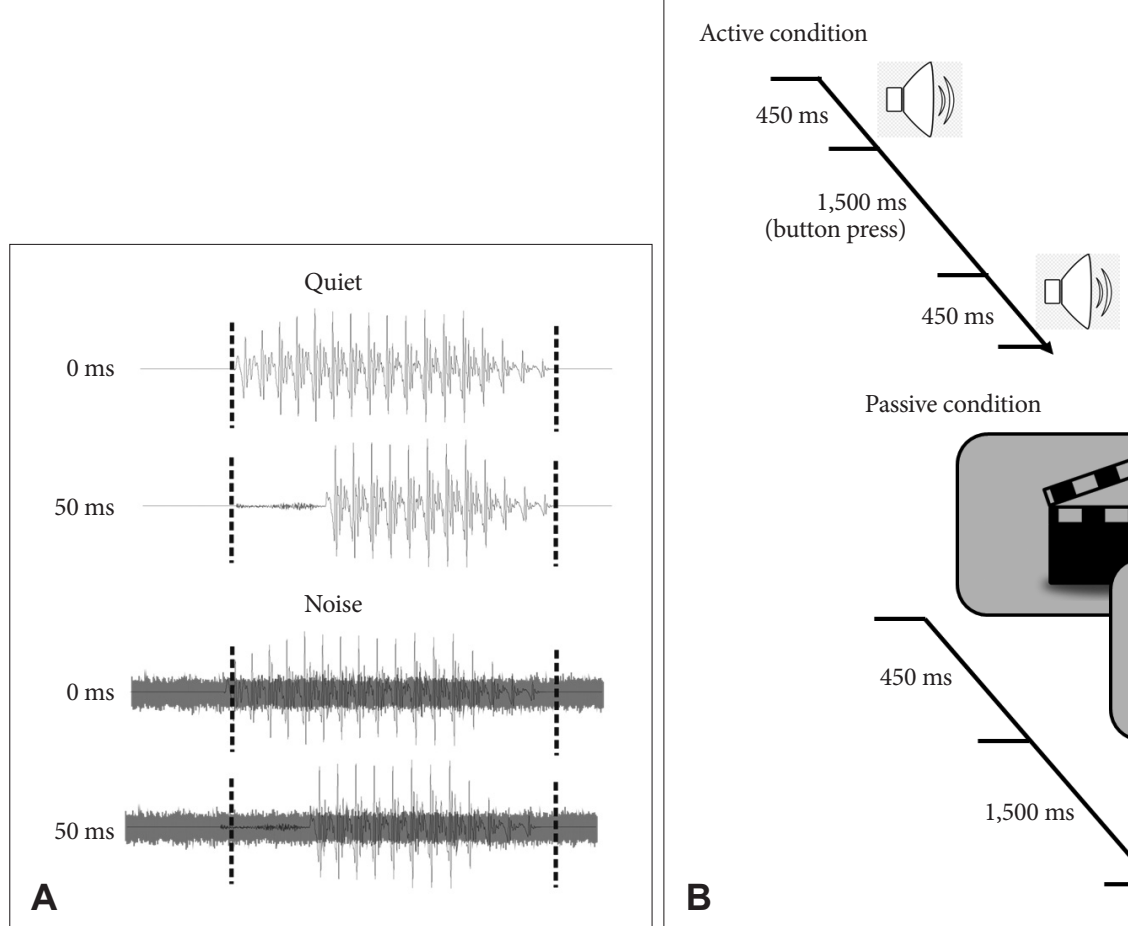

Passive condition

B

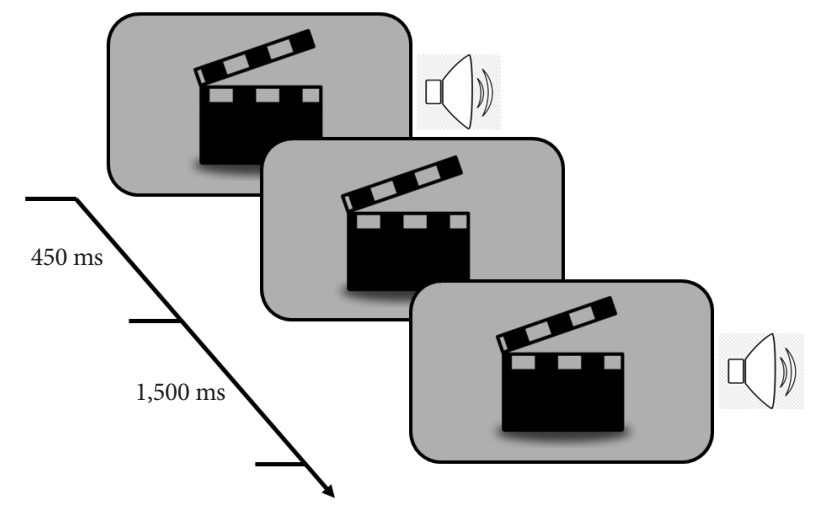

Figure 1. Experimental stimulus and design. A: Speech sounds with $0 \mathrm{~ms}$ and $50 \mathrm{~ms}$ VOTs were used in quiet (upper) and noise (bottom) conditions. B: Passive condition was followed by active condition. A duration of each VOT stimulus trial was 450 ms, and a fixed inter-stimulus interval $(1,500 \mathrm{~ms})$ was given for passive and active conditions. During active condition, participants had to press a button within the $1,500 \mathrm{~ms}$. VOT: voice onset time. 
다. 그러나 인공와우 사용자군은 인공와우 자체의 잡음이 많아 뇌파 측정에 영향을 미친다는 견본 데이터를 바탕으로 최소 400 개의 시행 수가 있어야 적절한 독립 성분 분석(independent component analysis, ICA)이 이루어진다고 제시되었기에 시행 수를 400회로 연장하여 진행하였다(Han et al., 2016). 다시 말 해서 각 VOT 자극음당 최소 400회(2 VOT $\times 400$ trials)를 실 행하였고, 능동 청취 조건을 4 블록, 그리고 수동 청취 조건은 2 블록으로 나누어 진행하였다.

자극음 사이 구간(inter-stimulus interval)은 1.5초로, 자극 음이 끝난 후 1.5 초의 휴지 구간을 지나 그 다음 자극음이 제 시되었고, 두 VOTs는 과제 수행 동안 무작위로 하나씩 제시되 었다. 이는 자극음이 나온 후, 피험자들에게는 1.5 초의 반응 시 간이 주어졌다는 것을 의미한다. 피험자의 반응에 대한 결과는 보여주지 않았다. 모든 자극음은 피험자로부터 $1.5 \mathrm{~m}$ 앞 정면에 위치한 스피커를 통해 쾌적 강도 레벨(most comfortable level) 수준의 크기로 차폐 방음실 안에서 제시되었다. 인공와우 사용 자들을 위한 소리의 쾌적 강도 레벨을 알기 위해, 0 부터 10 까지 11 종류의 소리 크기를 제시한 다음, 7 에 해당하는 크기의 자극 음을 추정한 후 실험을 진행하였다. 그러므로 인공와우 사용자의 경우 자극음의 소리 제시 강도가 변이적이었으며(70 85 dB SPL), 정상 청력군의 경우에는 $70 \mathrm{~dB} \mathrm{SPL}$ 로 일정하게 제시되었다.

\section{행동 검사}

자음과 모음 지각은 $\mathrm{Fu}(2002)$ 의 연구에 기반을 둔 강제 선 택 패러다임(forced choice paradigm)을 사용하여 측정하였다. 16 개의 자음은 신호 대 잡음 비율이 $+10 \mathrm{~dB}$ 인 음성 형태의 소 음하에서 남성 화자의 목소리로 "a/K/a"의 형태로 제시되었다. 각 자음은 5 번씩 $(5$ 회 $\times 16$ 자음 $)$ 총 80 회 수행되었다. 참가자들 은 자음을 듣고 16 개 중 적절한 답을 마우스로 클릭하도록 교 육받았다. 모음 지각은 “h/V/d"로 10 개의 단모음과 2 개의 이중 모음을 제시한 후 결과를 수치화하였다. 각 모음은 자음과 마 찬가지로 신호 대 잡음 비율이 $+10 \mathrm{~dB}$ 인 음성 형태의 소음하 에서 5 번씩(5회 $\times 12$ 모음), 총 60 회 제시되었다. 참가자들은 모음을 듣고 12 개 중 적절한 답을 마우스로 클릭하도록 교육받 았다. 모음과 자음 지각 검사의 수행도는 백분율로 수치화하였 다. 문장과 단어 지각은 소음하 말지각(speech perception in noise) 검사를 사용하여 측정하였다(Kalikow et al., 1977; Tiger Speech Technology, 2005). 총 50개의 문장은 신호 대 잡음 비율이 $+10 \mathrm{~dB}$ 인 음성 형태의 소음하에서 제시되었다. 참가자 들은 문장에서 각 단어를 듣고 따라 하도록 교육받았다. 핵심어 (문장의 마지막 단어)의 정답 개수는 백분율로 표시하였다. 고 빈도와 저빈도의 핵심어는 따로 평가하였다. 소음하에서의 모 든 말지각력(예: 모음, 자음, 그리고 소음하 말지각력 검사의 마
지막 단어)은 평균 점수(백분율)를 이용하여 복합 음성 지각 점수로 표시하였다. 양쪽 귀에 모두 인공와우를 이식하였을 경 우, 한쪽의 인공와우를 끄고 한쪽씩 검사를 수행하였다. 이후, 양쪽의 복합 점수를 비교하여 점수가 높은 쪽의 인공와우를 이용하여 뇌전도 실험을 실행하였다(총 오른쪽 6 명, 왼쪽 4명).

\section{뇌파 측정}

뇌파는 64 채널 뇌파측정기(actiChamp; brain products $\mathrm{GmbH}$, Munich, Germany)를 이용하여, 등거리로 위치한 전극이 부착 된 캡을 두피에 씨워 측정하였다(Debener et al., 2005; Han \& Dimitrijevic, 2015). 접지 전극은 비근점과 $\mathrm{Cz}$ 위치의 중간 지점 에 위치하도록 조절하였으며, 총 64개 중 한 개는 기준 전극으 로 $\mathrm{Cz}$ 에 위치하였고 나머지 63개의 전극으로 뇌파를 측정하였 다. 데이터 저장 시 표본율(sampling rate)은 $1,000 \mathrm{~Hz}$ 였고, 모 든 데이터는 오프라인 분석을 위해 저장되었다.

\section{데이터 처리}

Brain Vision Analyzer 2.0 (Brain Products $\mathrm{GmbH}$ )을 이용 하여 뇌파 데이터를 분석하였다. 측정된 뇌파는 먼저 고대역 통 과 필터(high-pass filter)를 이용하여 저주파에서 발생하는 잡 음 신호를 제거하기 위해 $0.01 \mathrm{~Hz}$ 이하 주파수를 차단하였고, 표본율을 $512 \mathrm{~Hz}$ 로 낮추었다. 또한, 통과 주파수 대역 필터링 (band-pass filter)을 사용하여 전원에 의해 발생하는 잡음 60 $\mathrm{Hz}$ )을 제거하였다. 이후 육안 검사(visual inspection)로 신체 움 직임과 관련된 잡음 $(500 \mathrm{mV}$ 초과)을 제거하였고, 독립 성분 분 석(ICA)을 통해 눈 깜빡임/좌우 움직임, 심전도(electrocardiography), 인공와우 잡음(cochlear implant artifact)을 제거하 였다(Delorme \& Makeig, 2004).

잡음 제거(artifact rejection)가 완료된 데이터는 저대역 통과 필터(low-pass filter)로 $20 \mathrm{~Hz}$ 이상의 주파수를 차단하였고, 자극 시작점인 $0 \mathrm{~ms}$ 를 기준으로 자극 전 $200 \mathrm{~ms}$ 에서부터 자극 후 $1,000 \mathrm{~ms}$ 까지 총 $1,200 \mathrm{~ms}$ 로 분할(segmentation)하여 분석 에 활용하였다. 각 VOT에 따라 나뉘어진 데이터는 조건당 실시 된 시행 수를 63 개의 전극별로 평균화하여 기준 전극의 평균값 으로 빼주었다. 이어서, 정면중앙(fronto-central)의 전극에서는 $\mathrm{N} 1 / \mathrm{P} 2$ 성분을, 두정엽(parietal)의 전극에서는 P3b 성분을 보기 위해, 정점(peak) 검출을 수행하였다.

\section{통계 분석}

인공와우 사용자의 우수군과 저조군 간의 반응 시간과 능동 대처 상황에서의 $/ \mathrm{pa} /$ 에 대한 정반응률에 대한 그룹 간 비교를 실시하기 위해 일원분산분석을 사용하였다. 또한 말지각력 검 사[모음, 자음, 단어(고빈도/저빈도), 문장]의 인공와우 저조군 
과 우수군의 수행력을 비교하기 위해 Mann-Whitney U test를 각각 실시하였다.

VOT (2 VOT), 집중도(능동/수동 청취 조건), 소음(소음의 유 무), 그리고 참가자 그룹(인공와우 사용자의 우수군 vs. 저조군 vs. 정상 청력군)의 영향을 살펴보기 위해 혼합모델 분산분석 (mixed model ANOVA)을 수행하여 N1의 진폭과 잠재기, P2 의 진폭과 잠재기, 그리고 $\mathrm{P} 3 \mathrm{~b}$ 의 진폭과 잠재기를 비교하였다. Tukey's honest significant difference 검증을 이용하여 사후 비교(post-hoc comparisons)를 수행하였다. 뇌 활동성과 말지 각력 간의 관계를 알아보기 위해, 스피어만 상관계수(Spearman correlation coefficient)를 이용하여 뇌 활동성과 소음하 말지 각력 수행도의 관련성을 검사하였다.

\section{RESULTS}

\section{행동 검사}

독립표본 $t$ 검정으로 인공와우 사용자 집단의 우수군과 저조 군에 대한 소음 조건에서의 말지각력을 비교한 결과, 인공와우 사용자의 우수군에서는 문장 $[t(10)=4.4, p<0.05]$, 어휘 전체 $[t(10)=2.9, p<0.05]$, 고빈도 어휘 $[t(10)=3.6, p<0.05]$, 자음 $[t(10)=4.2, p<0.05]$, 그리고 복합 점수 $[t(10)=5.2, p<0.05]$ 를 포함한 대부분의 말지각력 검사에서 소음의 유무에 따라 차 이가 관찰되었다. 그러나 저조군에서는 고빈도 어휘 $[t(6)=2.9$, $p<0.05]$ 에서만 소음 유무에 따른 차이가 관찰되었다.

Figure 2에서는 $0 \mathrm{~ms}$ 그리고 $50 \mathrm{~ms}$ 그룹의 VOT의 길이 변 화에 따른 $/ \mathrm{pa} /$ 인지율과 평균 반응 시간을 보여준다. 소음 조 건에서의 $0 \mathrm{~ms}$ VOT에 대한 $/ \mathrm{pa} /$ 인지율은 $12 \pm 13.8 \%, 32.8$ $\pm 31.3 \%$, 그리고 $31.1 \pm 14.9 \%$ (정상 청력군, 우수군, 그리고
저조군 순, 평균 \pm 표준편차)로 유의미한 차이는 보이지 않았 다. $50 \mathrm{~ms}$ VOT에서의 $/ \mathrm{pa} /$ 인지율은 $90.5 \pm 9.7 \%, 65.8 \pm$ $17.2 \%$, 그리고 $58.2 \pm 28.8 \%$ (정상 청력군, 우수군, 그리고 저조 군 순, 평균 \pm 표준편차)로 역시 유의미한 차이를 보이지 않았 다. 소음 조건에서의 $0 \mathrm{~ms}$ VOT에 대한 반응 시간은 $611.0 \pm$ $81.1 \mathrm{~ms}, 511.5 \pm 103.8 \mathrm{~ms}$, 그리고 $577.0 \pm 53.6 \mathrm{~ms}$ (정상 청력 군, 우수군, 그리고 저조군 순, 평균 \pm 표준편차)였다. 그리고 50 $\mathrm{ms}$ VOT에서의 반응 시간은 $584.4 \pm 85.8 \mathrm{~ms}, 535.1 \pm 113.8$ $\mathrm{ms}$, 그리고 $580.8 \pm 54.0 \mathrm{~ms}$ (정상 청력군, 우수군, 그리고 저 조군 순, 평균 \pm 표준편차)였고 두 조건에서 모두 유의미한 차 이는 나타나지 않았다.

\section{VOT에 따른 대뇌피질의 사건 유발전위}

\section{소음 효과}

진 폭

소음이 없는 청취 조건에서의 N1과 P2에 관한 결과는 본 연 구팀의 이전 논문에서 보고되었으므로(Han et al., 2016) 본 연 구에서는 소음 청취 조건에 대해서만 중점적으로 다루기로 한 다. 반복측정 변량분석(repeated measures ANOVA; 정상 청력 군/인공와우 우수군/인공와우 저조군 $\times$ 능동/수동 청취 조건 $\times$ 소음의 유/무 $\times$ VOT $0 / 50 \mathrm{~ms}$ ) 결과에 따르면 N1 진폭에서 의 유의미한 효과는 나타나지 않았다. 반면, P2 진폭의 경우 소 음 $\times$ 능동 청취 조건(집중 요 $) \times$ 그룹의 상호작용 $[\mathrm{F}(2,20)=$ $9.5, p<0.01]$ 그리고 $\mathrm{VOT}[\mathrm{F}(1,20)=5.8, p<0.05]$ 에서 유의 미하게 차이가 났다. 정상 청력군에서의 사후검정을 살펴보면, 소음이 없는 수동 청취 조건에서의 P2의 진폭의 크기가 소음

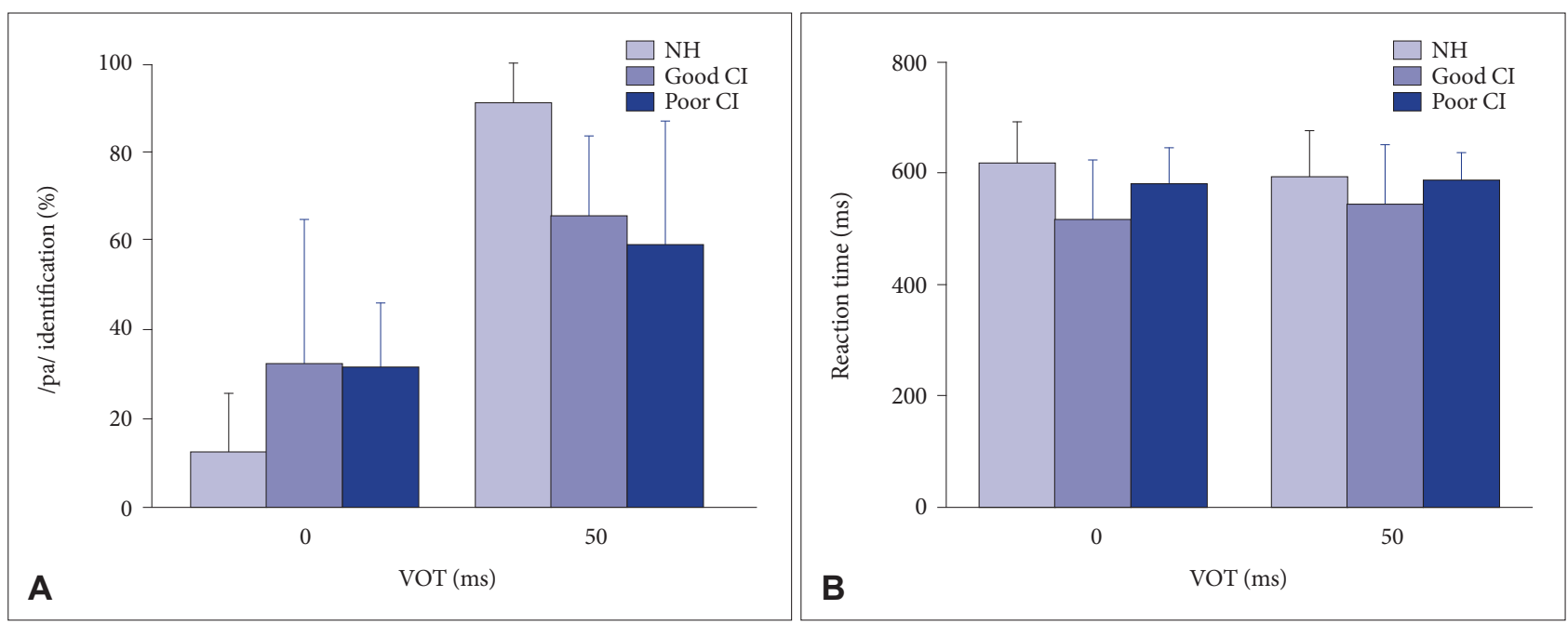

Figure 2. Results of behavioral task. A: Mean /pa/ identification scores in good and poor performing $\mathrm{Cl}$ groups for noise condition. B: Mean reaction times for $0 \mathrm{~ms}$ and $50 \mathrm{~ms}$ VOTs in noise condition for the three subject groups. No significant differences were found both in /pa/ identification and reaction time. Error bars are standard deviation. VOT: voice onset time, $\mathrm{NH}$ : normal hearing, Cl: cochlear implant. 
이 있는 수동 청취 조건, 소음이 없는 능동 청취 조건, 그리고 소음이 있는 능동 청취 조건을 포함한 다른 모든 조건에서의 그것보다 유의미하게 컸다(all $p<0.05)$. 그리고 $0 \mathrm{~ms}$ VOT에 서의 P2의 진폭의 크기는 $50 \mathrm{~ms} \mathrm{VOT}$ 의 P2 진폭보다 작았다 $(p<0.05) . \mathrm{P} 3 b$ 의 경우, 반복측정 변량분석(정상 청력군/인공와 우 우수군/인공와우 저조군 $\times$ 소음의 유/무 $\times$ VOT 0/50 ms)을 이용해 살펴본 결과 그룹 간 $[\mathrm{F}(2,18)=9.7, p<0.05]$ 과 소음의 유무 $[\mathrm{F}(1,18)=12.3, p<0.05]$ 에 따라 차이가 났다. 정상 청력 군에서의 P3b 진폭에 대한 사후검정을 실시했을 때, 인공와우 사용자군(우수/저조군 모두 $p<0.05$ )에 비해 P3b 진폭이 유 의미하게 컸으며, 능동 청취 조건에서 소음이 있을 때가 없을 때보다 작았다 $(p<0.05)$.

\section{잠재기}

피험자 그룹에 상관없이, N1과 P2의 잠재기는 능동과 수동 청취 조건에서 모두 소음에 의해 더 연장되었다. $\mathrm{N} 1$ 잠재기의 경우, 능동 청취 조건(집중) $\times$ 소음 $[\mathrm{F}(1,20)=5.5, p<0.05]$ 의 상호작용 그리고 소음 $\times \mathrm{VOT}$ 의 길이 $[\mathrm{F}(1,20)=6.0, p<0.05]$ 의 상호작용에서 유의미하게 차이가 났다. 사후검정을 통해 알 아본 결과, 능동 그리고 수동 청취 조건 모두, 소음에 의한 $\mathrm{N} 1$ 의 잠재기는 소음이 없는 조건에 비해 길었다(all $p<0.01) .0 \mathrm{~ms}$ $\mathrm{VOT}$ 에 대한 $\mathrm{N} 1$ 을 청취 조건이나, $\mathrm{VOT}$ 의 길이에 따라 비교해 보았다, $0 \mathrm{~ms}$ VOT가 주어졌을 때, $\mathrm{N} 1$ 의 변화를 능동 청취 조건 과 수동 청취 조건으로 비교해 보면 능동 청취 조건에서 잠재기 가 좀 더 길었다. 능동 청취 조건에서 VOT의 길이에 따른 N1을 비교해 보면, $0 \mathrm{~ms}$ VOT 자극이 주어졌을 때가 $50 \mathrm{~ms} \mathrm{VOT}$ 자극 이 주어졌을 때보다 잠재기가 유의미하게 짧았다(all $p<0.01)$. $\mathrm{P} 2$ 잠재기의 경우, $\mathrm{VOT}$ 길이 $[\mathrm{F}(1,21)=45.9, p<0.001]$ 의 상호 작용 그리고 소음 $\times$ 그룹 간 $[\mathrm{F}(2,21)=3.5, p<0.05]$ 의 상호 작용에 유의미한 차이가 관찰되었다. 사후검정 분석 결과 $\mathrm{P} 2$ 의
잠재기는 $50 \mathrm{~ms}$ 에 비해 $0 \mathrm{~ms}$ 의 VOT 조건에서 더 짧았고 $(p<$ 0.001), 인공와우 사용자 저조군에서의 소음이 있는 조건에서 관찰된 P2의 잠재기가 인공와우 사용자 우수군에서의 소음이 없는 조건에서 관찰된 $\mathrm{P} 2$ 의 잠재기보다 연장되었음을 확인하 였다. 또한 정상 청력군에서의 소음이 없는 조건에서 관찰된 $\mathrm{P} 2$ 의 잠재기에 비해서는 늦어졌다(all $p<0.05) . \mathrm{P} 2$ 잠재기에 대한 능동/수동 청취 조건에서의 차이는 보이지 않았다.

\section{소음하 말지각력에서 집중력의 효과}

Figure 3은 능동과 수동 청취 조건에서 소음이 있을 경우 $\mathrm{N} 1$ 그리고 $\mathrm{P} 2$ 의 파형을 보여준다. 반복측정 변량분석(정상 청 력군/인공와우 우수군/인공와우 저조군 $\times$ 능동/수동 청취 조 건 $\times 0 / 50 \mathrm{~ms} \mathrm{VOT}$ )을 통해 $\mathrm{N} 1$ 의 진폭 크기의 차이에 대해 분 석해 본 결과, 그룹 간[F(2,21) $=3.6, p<0.05]$ 의 차이가 유의 미하게 나타남을 확인하였는데, 사후검정을 실시한 결과, 정상 청력군의 N1 진폭 크기가 인공와우 저조군의 $\mathrm{N} 1$ 의 크기에 비 해 큰 것으로 나타났다. 조건에 따른 $\mathrm{N} 1$ 의 잠재기를 비교해 보면 그룹 간 $[\mathrm{F}(2,20)=5.2, p<0.05]$ 그리고 $\mathrm{VOT}$ 의 길이 $[\mathrm{F}(1,20)=$ $23.5, p<0.001]$ 에 따라 차이가 났으며, $\mathrm{P} 2$ 의 잠재기 비교 분석 에서 또한 그룹 간 $[\mathrm{F}(2,21)=6.6, p<0.01]$ 그리고 $\mathrm{VOT}$ 의 길 이 $[\mathrm{F}(1,20)=23.6, p<0.001]$ 에 의해 차이가 있음을 나타내었 다. 하지만 집중력에 따른 N1, P2의 유의미한 차이는 나타나지 않았다. 사후검정을 통해 인공와우 사용자 우수군에서의 N1과 $\mathrm{P} 2$ 의 잠재기가 정상 청력군의 두 가지 잠재기에 비해 지연되었 음을 확인하였다. 또한 VOT의 길이에 따른 N1과 P2의 잠재기 의 변화를 살펴보았을 때, 두 성분 모두 $0 \mathrm{~ms}$ VOT에서 $50 \mathrm{~ms}$ VOT에 비해 잠재기가 짧음을 알 수 있었다(all $p<0.05)$. Figure 4에서 보는 바와 같이, 소음 유무의 차이를 알아보기 위해 세 피험자군 내에서 말소리 길이에 따른 N1과 P2의 잠재기를 측정하였다. 수동 청취 조건에서 $\mathrm{N} 1$ 의 잠재기는 정상 청력군과

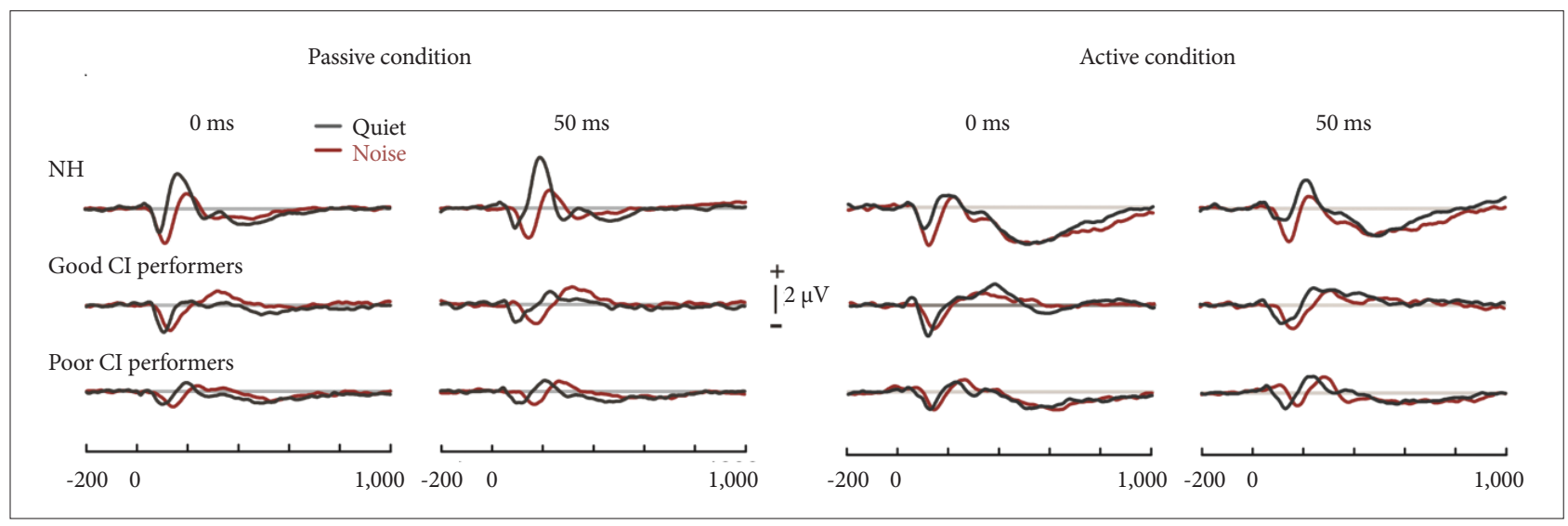

Figure 3. Grand mean waveforms to $0 \mathrm{~ms}$ and $50 \mathrm{~ms}$ voice onset times each with quiet and noise conditions for three subject groups. $\mathrm{NH}$ : normal hearing, $\mathrm{Cl}$ : cochlear implant. 

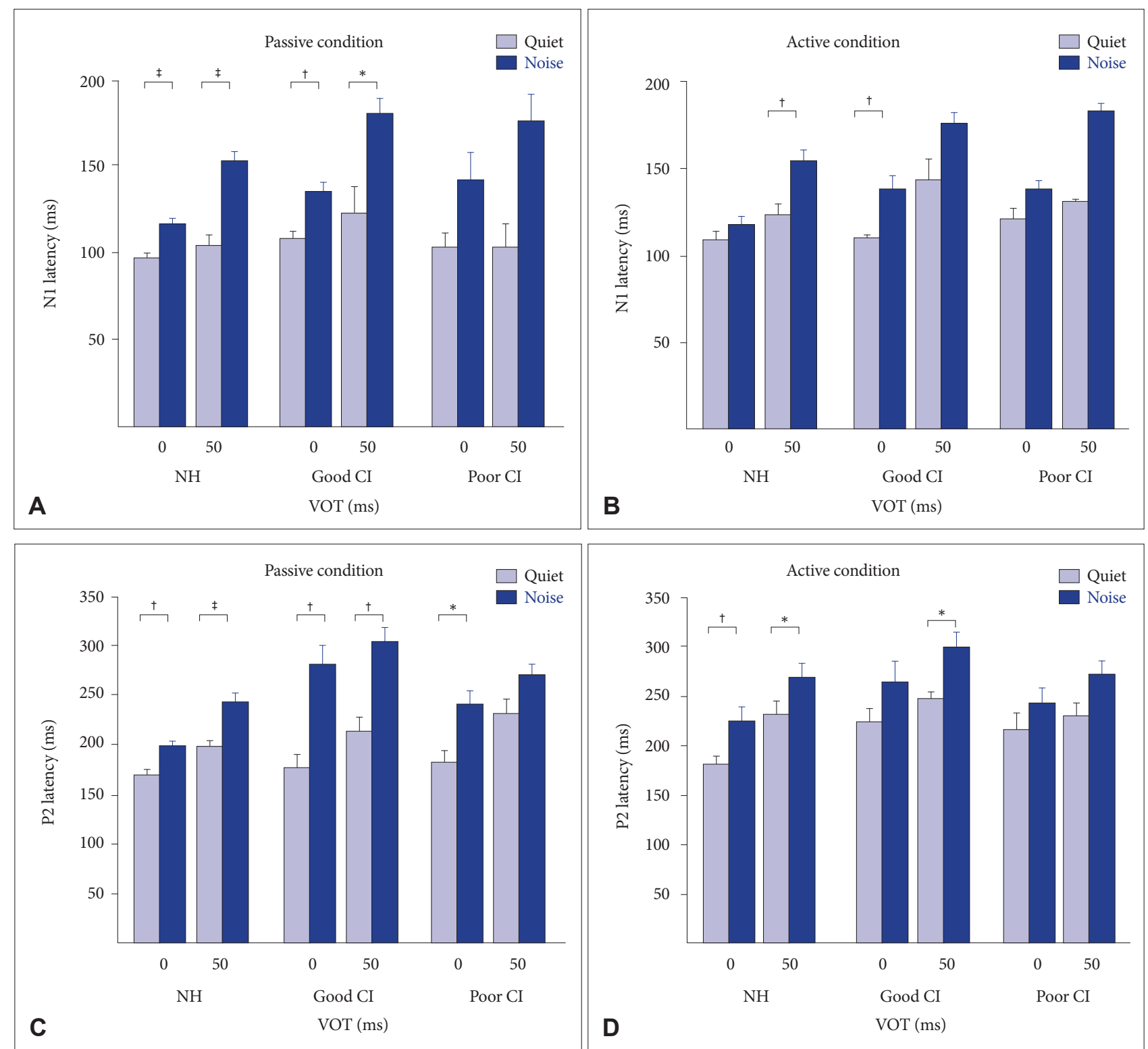

Figure 4. N1 and P2 latencies in quiet and noise conditions during passive or active condition for three subject groups. N1 latency was compared between quiet and noise conditions during passive (A) or active (B) listening among three subject groups. P2 latency was compared between quiet and noise conditions during passive (C) or active (D) listening among three subject groups. Error bars are standard error of the mean $\left({ }^{*} p<0.05,{ }^{\dagger} p<0.01,{ }^{\ddagger} p<0.001\right)$. Light blue bars represent N1 or P2 responses in quiet condition and blue bars indicate N1 or P2 responses in noise condition. VOT: voice onset time, $\mathrm{NH}$ : normal hearing, $\mathrm{Cl}$ : cochlear implant.

인공와우 우수군에서 $0 \mathrm{~ms}$ 그리고 $50 \mathrm{~ms}$ 에서 모두 소음의 유 무에 의해 유의미한 차이가 있었다(Figure 4A, C). 인공와우 저 조군에서는 $0 \mathrm{~ms}$ VOT 조건에서만 P2의 잠재기가 유의미한 차 이를 보였다. 능동 청취 조건에서도 차이가 있는 그룹이 있었다. $\mathrm{N} 1$ 의 잠재기는 정상 청력군의 $50 \mathrm{~ms} \mathrm{VOT}$ 조건과 인공와우 우 수군의 $0 \mathrm{~ms}$ VOT 조건에서만 유의미한 차이가 있었고, $\mathrm{P} 2$ 잠 재기는 정상 청력군의 두 가지 VOT 조건, 그리고 인공와우 우 수군에서는 $50 \mathrm{~ms}$ VOT 조건에서 유의미한 차이를 보였다 (Figure 4B, D).

\section{뇌파-행동 검사 상관관계}

본 연구팀이 이전에 발표한 논문에 따르면 조용한 상황에서 VOT 자극음으로 유발된 인공와우 사용자의 N1/P2와 말지각 점수와의 유의미한 상관관계가 밝혀진 바가 있으므로 본 연구 에서는 소음하 환경에서의 N1/P2와 소음하 말지각력과의 상 관관계를 알아보았다. Figure 5에서 보이는 바와 같이, 스피어 만 상관관계 분석 결과 $0 \mathrm{~ms}$ 와 $50 \mathrm{~ms}$ VOT에서 $\mathrm{P} 2$ 잠재기의 평균값(average all P2 latency)과 소음하에서의 소음하 모음 $(\mathrm{r}=0.64, p<0.05)$ 지각 점수가 유의미한 상관관계를 나타내 

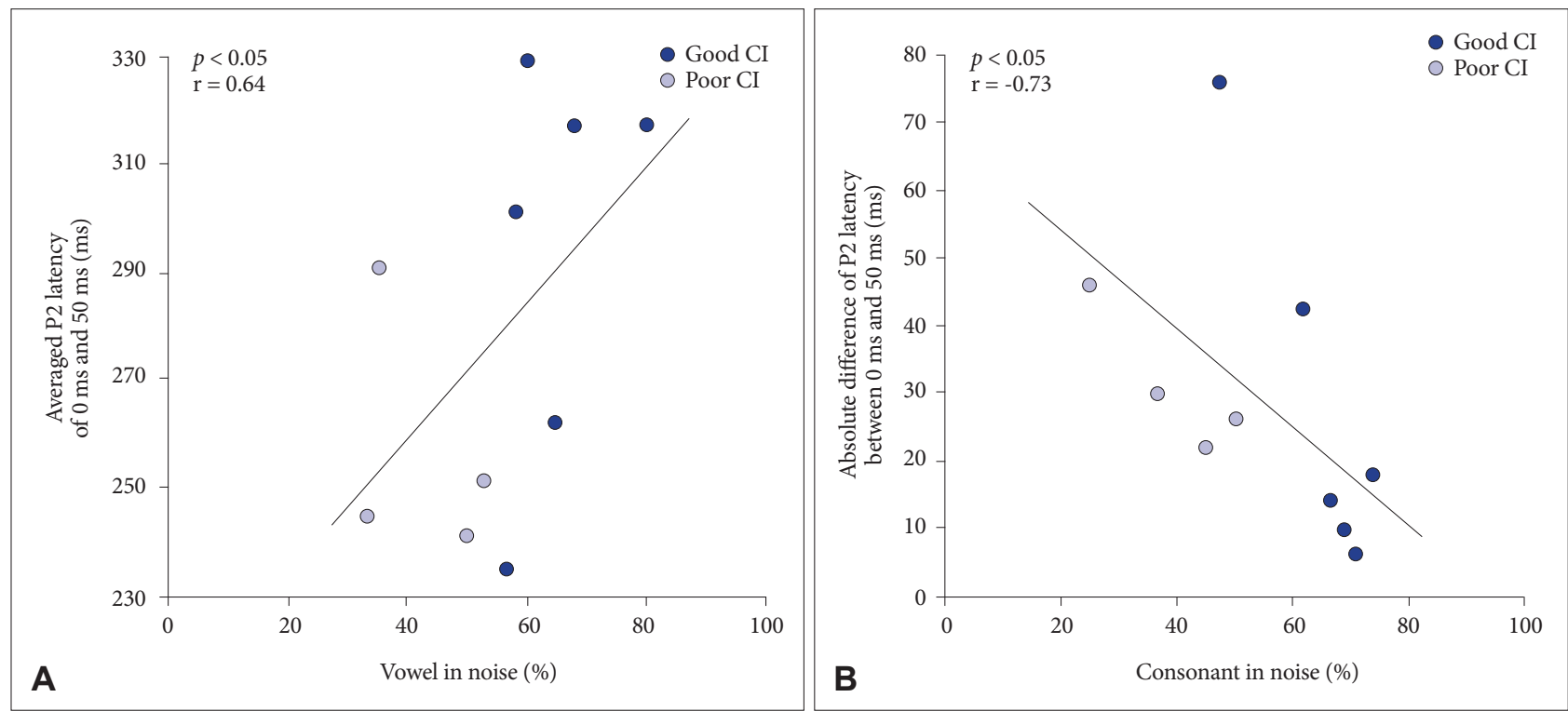

Figure 5. Significant Spearman's rank correlations between P2 latency and vowel and consonant perception in noise. A: Averaged P2 latency during $0 \mathrm{~ms}$ and $50 \mathrm{~ms}$ voice onset times were positively correlated with vowel in noise scores $(r=0.64, p<0.05)$. B: Absolute difference of P2 latencies ( $0 \mathrm{~ms}$ vs. $50 \mathrm{~ms}$ ) was negatively correlated with consonant in noise scores $(r=-0.73, p<0.05)$. Note that blue and light blue dots represent good and poor $\mathrm{Cl}$ performers, respectively. $\mathrm{Cl}$ : cochlear implant.

었다. 이는 인공와우 사용자의 모음 지각 점수가 좋을수록 잠 재기의 평균 길이 또한 증가하는 것을 의미한다. 또한, $0 \mathrm{~ms}$ 와 $50 \mathrm{~ms}$ VOT의 $\mathrm{P} 2$ 잠재기의 차이 값과 소음하에서의 자음 $(\mathrm{r}=$ $-0.73, p<0.05)$ 지각 점수가 유의미한 상관관계를 보였는데, 이 는 소음하 자음 지각 점수가 좋을수록 $0 \mathrm{~ms}$ 와 $50 \mathrm{~ms}$ 의 P2 잠 재기의 차이가 작아지는 것을 의미한다.

\section{DISCUSSIONS}

본 연구의 목적은 소음이 말소리에 의해 일어난 뇌 활동성에 어떠한 영향을 미치는지 알아보는 것이었다. 연구 결과, 소음이 있는 환경에서 $\mathrm{VOT}$ 변별 과제 시행 시, N1과 P2의 잠재기가 소음에 의해 연장된 것으로 나타났다. 하지만 예상과는 달리, 집중도 유무(능동 vs. 수동 청취 조건)에 따른 대뇌피질 청성 유 발전위를 비교해 보았을 때, 소음 환경에서 주의집중에 의한 뇌 활동성의 차이는 나타나지 않았다. 또한, 인공와우 사용자의 뇌 활동성과 행동적 말지각 능력과의 연관성을 살펴보았을 때, $\mathrm{P} 2$ 잠재기와 소음하 모음 및 자음 지각 능력과 유의미한 상관관계 를 나타내었다.

\section{행동적 말지각에 대한 소음의 영향}

본 연구에서는 인공와우 사용자를 대상으로 모음, 자음, 단 어, 문장을 포함한 다양한 수준의 행동적 말지각 평가를 각각 조용한 환경과 소음이 있는 환경에서 실시하여 행동적 말지각 에 대한 소음의 영향을 측정하였다. 예상한 바와 같이 수행력
이 우수한 인공와우군에서는 저빈도 어휘를 제외하고 모든 영 역에서 소음의 영향이 유의미하게 나타났으나, 인공와우 저조 군에서는 저빈도 어휘를 제외하고 모든 영역에서 차이를 보이지 않았다. 이는 인공와우 우수군의 소음에 대한 높은 민감도를 반 영한다고 볼 수 있으며, 저조군의 경우 소음의 유무에 관계없이 전체적으로 말지각력이 저조하기 때문에 소음의 영향 또한 우 수군에 비해 상대적으로 작게 나타난 것으로 추측된다. 본 연구 에 참가한 인공와우 사용자들은 한쪽 귀에만 인공와우를 착용 한 상태로 모든 실험에 참가하였는데, 양이(bilateral) 인공와우 사용자의 소음하 말지각력을 연구한 이전 연구에 의하면 양쪽 에 인공와우를 착용하였을 때 일측(unilateral) 인공와우를 착 용한 상태보다 소음하 문장과 단어 지각력이 우수하다고 보고 하였다(Müller et al., 2002). 따라서 본 연구에서 적용한 일측 인 공와우 청취가 인공와우 사용자의 소음에 대한 민감도를 높여, 낮은 소음하 말지각 능력을 야기한 것으로 생각된다. 또한, 인공 와우 우수군에서는 저빈도 어휘 과제에서만 조용한 환경과 소 음 환경에서의 차이를 보이지 않았는데, 이 과제의 경우 문맥에 서 나타나는 의미적 단서 없이 정확한 듣기 능력만으로 정답을 맞혀야 하기 때문에, 조용한 환경에서의 점수가 모든 항목을 통 틀어 가장 낮으며, 소음의 영향 또한 상대적으로 작기 때문으로 유추된다. 마찬가지로 인공와우 저조군에서는 고빈도 어휘 과제 에서만 조용한 환경과 소음 환경의 유의미한 차이를 보였는데, 고빈도 어휘 과제는 문맥의 의미적 단서가 주어지기 때문에 조 용한 상황에서는 높은 수행력을 보이나, 소음 환경에서는 지각 력이 저하되어 이러한 결과를 보인 것으로 추측된다. 


\section{$\mathrm{N} 1 / \mathrm{P} 2$ 대뇌피질 청성 유발전위에 대한 소음의 영향}

인공와우 사용자의 N1/P2에 대한 소음의 영향을 알아본 결 과, /ba/- $/ \mathrm{pa}$ / 연속체의 말소리에 의해 일어난 N1/P2의 잠재기 가 소음에 의해 크게 연장된 것으로 나타났다. 소음에 의한 N1/ P2의 변화를 조사한 선행 연구들에 의하면 톤(tone) (Bertoli et al., 2005), 화음(harmonic complex) (Alain et al., 2014), 그 리고 음성(Parbery-Clark et al., 2011; Shtyrov et al., 1999)과 같은 다양한 소리가 소음과 함께 자극음으로 주어지면, 소음이 없는 조용한 상황에 비해 N1/P2의 진폭이 감소한다고 보고하였 다. 그러나 말소리를 자극음으로 사용한 일부 연구에서는 N1/ $\mathrm{P} 2$ 대뇌피질 청성 유발전위의 잠재기가 진폭보다 소음에 의한 신 경 활성화의 변화에 더 민감하게 반응한다고 주장하였다. 예를 들면, VOT 변화에 따른 N1의 반응 양상을 살펴본 한 연구에서 는, 긴 VOT를 가진 말소리를 소음과 함께 제시하였을 때, 소음 이 없을 때의 $\mathrm{N} 1$ 에 비해 $\mathrm{N} 1$ 의 잠재기가 증가하였다고 보고하였 다(Dimitrijevic et al., 2013). 또한, /da/ 음절을 이용한 연구에 서는 소음의 크기를 점진적으로 증가시켰을 때 $\mathrm{N} 1 / \mathrm{P} 2$ 의 잠재 기가 크기의 변화에 비례하여 증가하였으나, N1 진폭의 변화는 순차적으로 나타나지 않았다(Sharma et al., 2014). 이 연구에 서는 소음에 따른 N1 진폭의 변화는 복잡하고 비체계적인 반 면, N1 잠재기의 변화는 소음의 크기에 비례하여 비교적 일정 한 패턴으로 변화한다고 주장하였다. 그러므로 본 연구에서 나 타난 소음에 따른 잠재기의 변화는 소음에 대한 인공와우 사 용자의 대뇌피질의 민감도를 반영하였다고 볼 수 있으며, 중추 청각 처리에 대한 소음의 영향을 측정할 때 잠재기가 진폭보다 더 효과적일 수 있다는 가설을 지지한다. 한편, N1 진폭은 뇌신 경 다발의 동시적인 활동성의 크기를 반영하는 반면, N1 잠재 기는 청각 정보의 처리 속도와 연관성이 높은 것으로 알려져 있다(Tremblay et al., 2003). 따라서 본 연구에서 나타난 잠재기 의 연장은 소음으로 인한 청각 정보의 처리 속도의 지연에 따른 것으로 유추되는데, 이는 소음 환경에서 정확한 말소리 지각을 위해 일차 청각중추 영역 외에 대뇌의 다른 영역과의 통합 처 리로 인하여 처리 속도가 지연되고, 이러한 지연이 연장된 N1 잠재기로 나타난 것으로 생각된다.

인공와우 사용자들의 소음하 말지각을 향상시키는 효과적인 방법 중 하나는 소리에 집중을 하도록 유도하는 것이다. 이렇게 소음하 말지각 과제를 수행 시 주의집중을 하면 행동적 지각력 의 향상뿐만 아니라 대뇌피질 신경 활동성의 변화를 야기할 수 있다. 선행 연구에서는 인공와우 사용자군과 정상 청력군에서 소음하 말지각 검사를 수행하는 동안 선택적 주의집중에 의한 청각피질의 변화가 관찰되었다고 보고하였다(Choi et al., 2013; Dimitrijevic et al., 2017). 한 연구에서는 소음하 숫자 인지에 대 한 주의집중의 영향을 신경 진동의 변화로 관찰하였는데, 능동
청취 상황에서의 알파 진동(alpha oscillation)의 동시성이 수 동 청취 상황과 비교하여 유의미하게 증가하였으며, 이러한 알 파 진동의 변화는 소음하 숫자 인지 점수와 유의미한 상관관계 를 보였다고 보고하였다(Dimitrijevic et al., 2017). 또한, 난청인 혹 은 인공와우 사용자를 대상으로 조용한 환경에서 자극음에 대한 선택적 주의집중을 하도록 유도한 청각 재활을 실시한 후, 소음 이 있는 환경에서의 언어 이해도를 측정하였을 때 수행력이 크게 상승된 것이 확인되었다(Oba et al., 2011; Schumann et al., 2014). 하지만, 본 연구에서는 소음 환경에서 주의집중으로 인한 N1/P2 의 변화가 나타나지 않았다. 이러한 상이한 결과에 대한 원인 은, 우선 대부분의 선행 연구에서는 mismatch negativity 실험 에서 사용하는 선택적 집중 패러다임(oddball paradigm)을 이 용한 반면, 본 연구에서는 자극에 지속적으로 주의를 요하는 비 선택적 집중 패러다임(equiprobable paradigm)을 사용하였기 때문으로 추측된다. 청각적 자극에 대한 피험자들의 적극적인 선택을 요구하는 선택적 집중 패러다임을 사용한 이전 연구에 따르면, 소음 환경에서 자극에 주의집중을 하지 않았을 때 N1 진폭은 감소하고, 반대로 자극에 집중을 하면 N1 진폭이 증가 하였다(Choi et al., 2013). 반면, 본 연구의 참가자들은 주어지 는 자극음을 듣고 $/ \mathrm{ba} /$ 와 $/ \mathrm{pa} /$ 둘 중 하나를 무조건 선택하는 과제를 수행했기 때문에 모든 자극음에 주의집중이 요구되었다. 따라서 과제의 특성에 따라 주의집중을 처리하는 메커니즘이 달라져 다른 뇌 영역을 자극하게 되고, 서로 상이한 신경 활성 화 루트를 거치기 때문에 $\mathrm{N} 1$ 의 변화도 다르게 나타난 것으로 추측된다.

\section{대뇌피질 청성 유발전위와 소음하 말지각 능력과의 상관관계}

본 연구팀은 이전 연구에서 성인 인공와우 사용자를 대상으 로 VOT 차이에 따른 N1/P2의 변화를 살펴봄으로써 VOT와 대 뇌피질 청성 유발전위와의 관계를 조사하였는데 연구 결과, 말 지각력이 저조한 인공와우 그룹의 P2 잠재기가 우수한 인공와 우 그룹과 비교했을 때 크게 연장되었으며, 이러한 P2 잠재기의 변화는 모음 지각력과 유의미한 상관관계를 나타내었다(Han et al., 2016). 따라서 이 연구에서는 P2가 N1보다 인공와우 사 용자의 말지각력과 더 큰 연관성을 보인다고 주장하였다. 이와 유사하게, Kelly 연구팀의 인공와우 사용자 대상 연구 결과에 서도 음향적 변화를 포함하는 자극음으로 유발된 P2의 진폭 이 인공와우 사용자의 말지각력과 유의미한 상관관계를 나타 내었다(Kelly et al., 2005). 이러한 선행 연구 결과에 근거하여 본 연구에서는 VOT 정보를 포함한 말소리에 의해 발생한 N1 과 P2의 진폭과 잠재기가 인공와우 사용자들의 말지각력과 연 관성이 있는지를 알아보기 위해, 자극음이 소음과 함께 제시되 었을 때의 $\mathrm{N} 1 / \mathrm{P} 2$ 와 소음하 말지각 점수 사이의 상관관계를 조 
사하였다. 예상한 대로 $0 \mathrm{~ms}$ 와 $50 \mathrm{~ms} \mathrm{VOT}$ 자극음에 대한 P2 잠재기 수치들의 평균값과 차이값이 소음하 말지각 점수와 유 의미한 상관관계를 보였다. 특히 P2 잠재기가 길어질수록 소음 하 모음 지각 점수가 높아졌는데, 이는 소음으로 인해 정확한 듣기가 어렵기 때문에 일차 청각중추 이외에도, 주의집중과 청 지각 변별을 위해 전두엽, 두정엽 등의 다른 대뇌피질 부위가 뇌 활성화에 관여함으로써 나타나는 중추청각 처리의 연장이 길어진 P2 잠재기로 표현된 것으로 유추된다. P2는 청각적 훈련 혹은 청각적 변별과 연관이 깊은 것으로 보고되고 있는데, 훈련 이 지속되고 청각적 변별 능력이 향상될수록, 그리고 소리에 대 한 주의집중을 할수록 P2의 진폭이 증가된다고 알려져 있다 (Ross \& Tremblay, 2009; Tremblay et al., 2001). 이러한 P2의 특성은 $\mathrm{P} 2$ 를 일으키는 대뇌피질에서의 진원지와 연관성이 깊은 데, P2는 N1과 달리 일차 청각피질, planum temporale 외에도 다수의 진원지를 가지고 있는 것으로 알려져 있다(Godey et al., 2001). 따라서 이러한 다수의 진원지를 거치며 나타난 중추청각 처리의 지연이 P2 잠재기의 연장으로 반영된 것으로 생각된다.

상관관계 분석 결과, VOT $0 \mathrm{~ms}$ 와 $50 \mathrm{~ms}$ 에 대한 $\mathrm{P} 2$ 잠재기의 차이가 작을수록 소음하 자음 지각 점수가 높은 것으로 나타 났는데, 이는 상대적으로 긴 VOT $(50 \mathrm{~ms})$ 를 처리할 때도 $0 \mathrm{~ms}$ 의 짧은 VOT를 처리하는 것과 유사한 빠른 청각적 처리가 가 능한 것을 의미하므로, 소음하 말지각 능력이 우수한 인공와우 사용자일수록 높은 신경 동시성(neural synchrony)과 빠른 신 경 전달이 가능하며, 이러한 신경적 우수성이 빠른 P2 잠재기 로 투영된 것으로 생각된다. 결과를 요약하면 본 연구는 P2 잠 재기가 인공와우 사용자들의 말지각력에 대한 객관적 척도로 사용될 수 있는 가능성을 가지고 있음을 시사한다. 대뇌피질 청성 유발전위와 말지각 검사를 포함하는 행동적 수행력과의 상관관계를 밝히는 것은 특히 영유아와 같은 주관적 평가 방식 의 적용이 어려운 평가 대상을 위한 중요한 정보로서, 이들의 말지각력에 대한 객관적인 지표를 개발하는 데 도움을 줄 수 있 기 때문에 임상적으로 큰 의의가 있다. 하지만 선행 연구에 따 르면, 클릭 혹은 tone burst 같은 단순 자극음과 비교하여 환경 친화적인 자극을 사용하였을 때 임상 집단에서 대뇌피질 청성 유발전위와 말지각력 사이의 상관관계가 더 높게 나타났다(Abbas \& Brown, 1991). 따라서 후속 연구에서는 의미가 있는 문 장이나 단어와 같은 좀 더 자연스러운 자극음을 이용하여 인 공와우 사용자의 말지각력과 뇌 활동성과의 상관관계를 조사 하는 것이 필요하다(Michalewski et al., 2009).

결론적으로 본 연구에서는 소음이 N1과 P2의 잠재기를 유 의미하게 증가시키며, P2 잠재기가 인공와우 사용자의 말지각 능력과 상관관계가 있다는 것을 보여주었다. 이러한 결과를 종 합해 보면, 소음은 행동적으로 말지각력을 변화시키고 이러한
행동적 변화는 대뇌피질 청성 유발전위에 의해 측정된 신경 활 동성의 변화로 나타날 수 있음을 시사한다. 본 연구 결과의 연 장선상에서 후속 연구에서는 귀의 자극 방향에 따른 효과를 조사하고, 더 큰 인공와우 표본 수를 이용한 연구가 진행되어 야 할 것이다.

중심 단어 : 인공와우·소음하 말지각력· 대뇌피질 청성 유발전위·음성 개시 시간.

\section{Ethical Statement}

This study is approved by Institutional Review Board of Cincinnati Children's Hospital Medical Center (IRB\# 2013-0105).

\section{Acknowledgments N/A}

\section{Declaration of Conflicting Interests}

There are no conflict interests.

\section{Funding}

This project was supported in part by Basic Science Research Program through the National Research Foundation of Korea (NRF) funded by the Ministry of Education (2017R1D1A1B03030613) and by the Center for Women in Science, Engineering and Technology (WISET) Grant funded by the Ministry of Science, ICT \& Future Planning of Korea (MSIP) under the Program for Returners into R\&D (WISET-2018-092).

\section{REFERENCES}

Abbas, P. J. \& Brown, C. J. (1991). Electrically evoked auditory brainstem response: Refractory properties and strength-duration functions. Hearing Research, 51(1), 139-147.

Alain, C., Roye, A., \& Salloum, C. (2014, January 31). Effects of age-related hearing loss and background noise on neuromagnetic activity from auditory cortex. Frontiers in Systems Neurosciencen [Epub ahead of print]. https://doi.org/10.3389/fnsys.2014.00008.

Anderson, S., White-Schwoch, T., Parbery-Clark, A., \& Kraus, N. (2013). A dynamic auditory-cognitive system supports speech-in-noise perception in older adults. Hearing Research, 300, 18-32.

Bertoli, S., Smurzynski, J., \& Probst, R. (2005). Effects of age, age-related hearing loss, and contralateral cafeteria noise on the discrimination of small frequency changes: Psychoacoustic and electrophysiological measures. JARO-Journal of the Association for Research in Otolaryngology, 6(3), 207-222.

Bidelman, G. M. \& Howell, M. (2016). Functional changes in inter- and intra-hemispheric cortical processing underlying degraded speech perception. Neuroimage, 124(Pt A), 581-590.

Choi, I., Rajaram, S., Varghese, L. A., \& Shinn-Cunningham, B. G. (2013). Quantifying attentional modulation of auditory-evoked cortical responses from single-trial electroencephalography. Frontiers in Human Neuroscience, 7, 115.

Debener, S., Makeig, S., Delorme, A., \& Engel, A. K. (2005). What is novel in the novelty oddball paradigm? Functional significance of the novelty P3 event-related potential as revealed by independent component analysis. Brain Res Cogn Brain Res, 22(3), 309-321.

Delorme, A. \& Makeig, S. (2004). EEGLAB: An open source toolbox for analysis of single-trial EEG dynamics including independent component analysis. Journal of Neuroscience Methods, 134(1), 9-21.

Dimitrijevic, A., Pratt, H., \& Starr, A. (2013). Auditory cortical activity in normal hearing subjects to consonant vowels presented in quiet and in 
noise. Clinical Neurophysiology: Official Journal of the International Federation of Clinical Neurophysiology, 124(6), 1204-1215.

Dimitrijevic, A., Smith, M. L., Kadis, D. S., \& Moore, D. R. (2017). Cortical alpha oscillations predict speech intelligibility. Frontiers in Human Neuroscience, 11, 88.

$\mathrm{Fu}, \mathrm{Q}$. J. (2002). Temporal processing and speech recognition in cochlear implant users. NeuroReport, 13(13), 1635-1639.

Fu, Q. J. \& Galvin, J. J. 3rd. (2008). Maximizing cochlear implant patients' performance with advanced speech training procedures. Hearing Research, 242(1-2), 198-208.

Fu, Q. J. \& Nogaki, G. (2005). Noise susceptibility of cochlear implant users: The role of spectral resolution and smearing. JARO-Journal of the Association for Research in Otolaryngology, 6(1), 19-27.

Godey, B., Schwartz, D., de Graaf, J. B., Chauvel, P., \& Liégeois-Chauvel, C. (2001). Neuromagnetic source localization of auditory evoked fields and intracerebral evoked potentials: A comparison of data in the same patients. Clinical Neurophysiology: Official Journal of the International Federation of Clinical Neurophysiology, 112(10), 1850-1859.

Han, J. H. \& Dimitrijevic, A. (2015). Acoustic change responses to amplitude modulation: A method to quantify cortical temporal processing and hemispheric asymmetry. Frontiers in Neuroscience, 9, 38.

Han, J. H., Zhang, F., Kadis, D. S., Houston, L. M., Samy, R. N., Smith, M. L., et al. (2016). Auditory cortical activity to different voice onset times in cochlear implant users. Clinical Neurophysiology: Official Journal of the International Federation of Clinical Neurophysiology, 127(2), 1603-1617.

Hopkins, K. \& Moore, B. C. (2009). The contribution of temporal fine structure to the intelligibility of speech in steady and modulated noise. The Journal of the Acoustical Society of America, 125(1), 442-446.

Huyck, J. J. \& Johnsrude, I. S. (2012). Rapid perceptual learning of noisevocoded speech requires attention. The Journal of the Acoustical Society of America, 131(3), EL236-EL242.

Kalikow, D. N., Stevens, K. N., \& Elliott, L. L. (1977). Development of a test of speech intelligibility in noise using sentence materials with controlled word predictability. The Journal of the Acoustical Society of America, 61(5), 1337-1351.

Kelly, A. S., Purdy, S. C., \& Thorne, P. R. (2005). Electrophysiological and speech perception measures of auditory processing in experienced adult cochlear implant users. Clinical Neurophysiology: Official Journal of the International Federation of Clinical Neurophysiology, 116(6), 12351246.

Michalewski, H. J., Starr, A., Zeng, F. G., \& Dimitrijevic, A. (2009). N100 cortical potentials accompanying disrupted auditory nerve activity in auditory neuropathy (AN): Effects of signal intensity and continuous noise. Clinical Neurophysiology: Official Journal of the International Federation of Clinical Neurophysiology, 120(7), 1352-1363.

Müller, J., Schön, F., \& Helms, J. (2002). Speech understanding in quiet and noise in bilateral users of the MED-EL COMBI 40/40+ cochlear implant system. Ear and Hearing, 23(3), 198-206.

Niemitalo-Haapola, E., Haapala, S., Jansson-Verkasalo, E., \& Kujala, T. (2015). Background noise degrades central auditory processing in toddlers. Ear and Hearing, 36(6), e342-e351.

Oba, S. I., Fu, Q. J., \& Galvin, J. J. 3rd. (2011). Digit training in noise can im- prove cochlear implant users' speech understanding in noise. Ear and Hearing, 32(5), 573-581.

Parbery-Clark, A., Marmel, F., Bair, J., \& Kraus, N. (2011). What subcortical-cortical relationships tell us about processing speech in noise. European Journal of Neuroscience, 33(3), 549-557.

Paredes-Gallardo, A., Innes-Brown, H., Madsen, S. M. K., Dau, T., \& Marozeau, J. (2018). Auditory stream segregation and selective attention for cochlear implant listeners: Evidence from behavioral measures and event-related potentials. Frontiers in Neuroscience, 12, 581.

Ponton, C. W., Don, M., Eggermont, J. J., Waring, M. D., \& Masuda, A. (1996). Maturation of human cortical auditory function: Differences between normal-hearing children and children with cochlear implants. Ear and Hearing, 17(5), 430-437.

Rao, A., Zhang, Y., \& Miller, S. (2010). Selective listening of concurrent auditory stimuli: An event-related potential study. Hearing Research, 268 (1-2), 123-132

Roelfsema, P. R., van Ooyen, A., \& Watanabe, T. (2010). Perceptual learning rules based on reinforcers and attention. Trends in Cognitive Sciences, 14(2), 64-71.

Ross, B. \& Tremblay, K. (2009). Stimulus experience modifies auditory neuromagnetic responses in young and older listeners. Hearing Research, 248(1-2), 48-59.

Rouger, J., Lagleyre, S., Fraysse, B., Deneve, S., Deguine, O., \& Barone, P. (2007). Evidence that cochlear-implanted deaf patients are better multisensory integrators. Proceedings of the National Academy of Sciences of the United States of America, 104(17), 7295-7300.

Schumann, A., Hast, A., \& Hoppe, U. (2014). Speech performance and training effects in the cochlear implant elderly. Audiology and Neurotology, 19 Suppl 1, 45-48

Sharma, M., Purdy, S. C., Munro, K. J., Sawaya, K., \& Peter, V. (2014). Effects of broadband noise on cortical evoked auditory responses at different loudness levels in young adults. Neuroreport, 25(5), 312-319.

Shtyrov, Y., Kujala, T., Ilmoniemi, R. J., \& Näätänen, R. (1999). Noise affects speech-signal processing differently in the cerebral hemispheres. Neuroreport, 10(10), 2189-2192.

TigerSpeech Technology (2005). Internet-based Open-set Speech Recognition (i-STAR): Version 2.04.02 (192 Mb). TigerSpeech Technology. Retrieved from http://www.tigerspeech.com/tst istar.html.

Tremblay, K., Kraus, N., McGee, T., Ponton, C., \& Otis, B. (2001). Central auditory plasticity: Changes in the N1-P2 complex after speech-sound training. Ear and Hearing, 22(2), 79-90.

Tremblay, K. L., Piskosz, M., \& Souza, P. (2003). Effects of age and age-related hearing loss on the neural representation of speech cues. Clinical Neurophysiology: Official Journal of the International Federation of Clinical Neurophysiology, 114(7), 1332-1343.

Won, J. H., Drennan, W. R., \& Rubinstein, J. T. (2007). Spectral-ripple resolution correlates with speech reception in noise in cochlear implant users. JARO-Journal of the Association for Research in Otolaryngology, 8(3), 384-392

Zhang, C., Lu, L., Wu, X., \& Li, L. (2014). Attentional modulation of the early cortical representation of speech signals in informational or energetic masking. Brain and Language, 135, 85-95. 